\title{
Sport, militarism and diplomacy: training bodies for China (1960-1966)
}

To cite this article: (2012) Sport, militarism and diplomacy: training bodies for China (1960-1966), The International Journal of the History of Sport, 29:1, 30-52, DOI: $10.1080 / 09523367.2012 .634983$

To link to this article: https://doi.org/10.1080/09523367.2012.634983

曲 Published online: 15 Feb 2012.

Submit your article to this journal $\pi$

Џ Article views: 329

Q View related articles $₫$

4 Citing articles: 1 View citing articles 


\title{
Sport, militarism and diplomacy: training bodies for China (1960-1966)
}

\begin{abstract}
After the Great Leap Forward, the Chinese government changed its strategy from 'Go all out, aim high and achieve greater, faster, better and more economic results' to 'Readjustment, consolidation, filling out and raising standards'. (调整、巩固、充实、提高). The Chinese Sport Ministry, in term, also changed its strategy of a mass sports campaign and moved towards using limited resources to raise the standards of competitive sport and to produce world class athletes. Also in this period, China faced the Sino-India border conflict, the Sino-Soviet split and the Vietnam War all of which influenced China's domestic and foreign policies and which, in turn, had profound impact on Chinese sports policy and practice. Sport had never before been so close to militarism. Some major sports events such as the Fourth Asian Games in 1962, the Games of the Newly Emerging Forces (GANEFO) in 1964 and the Second National Games in 1965, took place in this period and added more complexity to Chinese politics and diplomacy.
\end{abstract}

\section{The rise of sports militarism}

Three crucial factors contributed to the rise of sports militarism in the first half of the 1960s. The first was the Sino-Indian Border Conflict which was caused by a dispute over the sovereignty of three sectors claimed by both China and India. The departing British had left the Sino-Indian border undefined when India became independent in 1947. Although China's other neighbours faced similar problems, borders had been settled satisfactorily through diplomatic negotiations. However, India refused Beijing's call for negotiations and a 'standstill agreement' to prevent clashes in 1958. Nehru began to accuse China of 'aggression' because the Chinese Communist Party refused to surrender to Indian claims. ${ }^{1}$

India initiated an assertive policy of sending troops into the disputed regions in 1959 and this resulted in several conflicts between the two sides. ${ }^{2}$ Despite repeated warnings from Beijing India attempted in 1961 to a establish military presence in all the disputed territories in order to repel the Chinese. On 12 October 1962, Nehru officially proclaimed India's intention to take over the disputed areas. China took it as a declaration of war and responded that the Chinese were not going to wait to be attacked. ${ }^{3}$ Eight days later, the Chinese launched an offensive and forced the Indian troops to retreat some distance. The war ended on 20 November 1962 when China declared a ceasefire and showed its intention to withdraw. Over the following months, in order to show goodwill, ${ }^{4}$ Chinese troops retreated to the north of the McMahon Line and kept to the territory in Tibet which they had claimed in $1960 .^{5}$ 
The Central Intelligence Agency's (CIA) 1964 reports showed that it was India's offensive forward policy that had provoked China's counterattack. Neville Maxwell, a British scholar, concluded,

When China crushed India in 1962, the fault lay with India, or more specifically, it was a hopelessly ill-prepared Indian Army that provoked China on orders emanating from Delhi, and paid the price for its misadventure in men, money and national humiliation. ${ }^{6}$

The second incident was the Sino-Soviet split. In the context of the cold war, the People's Republic of China (PRC) and the USSR were close allies during the Stalin era. After Stalin passed away in 1953, his ideology, theory and policies were abolished by his successor Nikita Khrushchev, the first secretary of the Communist Party of the Soviet Union (CPSU). Khrushchev adopted new domestic and foreign policies, hoping to build up the strength of the country. He also initiated a campaign of de-Stalinisation in February 1956, accusing Stalin of causing terror, deportations and executions in the late Stalin era.

When the news was reported in China, the Chinese Communist Party (CCP) leaders questioned Khrushchev's theory. Chairman Mao enjoyed supreme power in the CCP as had Stalin in the CPSU. De-Stalinisation may have threatened his power and he criticised Khrushchev's call for de-Stalinisation. Also the USSR's new foreign policy favoured a peaceful coexistence with the United States and undermined the Sino-Soviet alliance. The CCP leaders believed that Khrushchev had betrayed not only the Stalinist Road but also Marxism and Leninism. Consequently, ideological conflicts between the PRC and the USSR began to grow. ${ }^{7}$

The Sino-Soviet friendship was further ruined by several incidents that happened in 1958 and $1959 .{ }^{8}$ By the end of the 1950s, the CPSU believed that the CCP was not really Marxist, whereas the CCP leaders were convinced that the CPSU had betrayed Stalinism, Leninism and Marxism. The Sino-Soviet alliance was on the verge of collapse. ${ }^{9}$ In July and August 1959, the Soviet Union cancelled all foreign aid projects and pulled out of the PRC the Soviet specialists working there. ${ }^{10}$ After the Sino-Indian border conflict broke out in August 1959, the Soviet News Agency (TASS) publicly announced on 9 September 1959 that the USSR supported India. ${ }^{11}$ A few days later, between 15 and 28 September 1959, Khrushchev paid his visit to the United States. These two incidents indicated that the Sino-Soviet friendship had reached an end. ${ }^{12}$

In addition, the CCP leaders regarded the Vietnam War as an offensive of the United States against China. After the 1954 Geneva Agreement, Vietnam was divided into two parts: the Democratic Republic of Vietnam (DRV) led by the Vietnamese Workers' Party (VWP) in the North and the Republic of Vietnamese (Southern Vietnam) led by a pro-American government. ${ }^{13}$ Although China did not publicly support North Vietnam, the PRC provided a great amount of aid to the DRV between 1956 and 1963. ${ }^{14}$ The CCP leaders believed that by supporting the Communist regime in Vietnam, China could secure its interests in East Asia and compete against the capitalist bloc led by the United States.

In response to the United States' incursion in Vietnam in the early 1960s, the Chinese government decided to provide more support for the DRV. Subsequently, the Chinese government offered the DRV, free of charge, 90,000 firearms. In August 1964, the US President Johnson decided to use military forces to support South Vietnam and protect America's interests in Southeast Asia. ${ }^{15}$ The USA went on to 
launch a series of military actions against North Vietnam in early $1965 .{ }^{16}$ The CCP leaders were worried about possible military threats from the United States and announced in April 1965 that it was the obligation of the Chinese people and the CCP to support the North Vietnamese communists. ${ }^{17}$

China now, 10 years after the Korean War, faced more military threats and the danger of national security from India, Taiwan, South Vietnam, the USA and the Soviet Union. At a meeting with General Vo Nguyen Giap, the DRV's Defence Minister, on 5 October 1962, Mao Zedong stated, 'In the past few years, we did not think much about the possible attacks from the imperialists. Now we must carefully think about it'. ${ }^{18}$ National security moved to centre stage and the concept 'Prepare for War, Fight against the Invaders' was at the core of China's domestic and foreign policies.

Meanwhile in sports matters, in March 1960 the Sports Ministry issued the 'Directive on the Establishment of National Defence Sports Clubs'. In April, the Ministry of Education and Ministry of Health issued the 'Announcement on Promotion of Patriotic Sports and Health Activities in Education Sectors'; in January 1961, the Sports Ministry and the Ministry of National Defence jointly issued the 'Notification on the Promotion of Aviation Clubs'. ${ }^{19}$

One of the major preparations for war was to develop military sport to train students, the youth and Chinese people to be skilled militia men and women. A nationwide campaign was initiated to promote mass military training. ${ }^{20}$ The Office of Civil Defence (人民武装部) was established at every level of the country: from the people's communes to factories; from schools to government departments. One of their functions was to liaise with sports organisations, education bureaux and army to training people to be soldiers for the possible wars. The slogan was 'To train all Chinese citizens to be soldiers' (全民皆兵).

All people aged 16 to 25 were encouraged to join the militia. However, before they could join they would have to pass a serious 'political examination' (政审). Only those who came from the families of three generations of poor peasants and workers were allowed to join the militia. The elite troops of the militia were called 'the backbone militia' (基干民兵). People from a family background of landlords, industrialists, bourgeoisie and anti-revolutionaries, were strictly forbidden to join the militia, since the Party would not trust them to hold guns in their hands.

Military training activities included swimming, long distance running, shooting, mountain climbing, martial arts, radio sport (无线电运动), aero modelling (航模), marine modelling (海模) and parachute jumping. Some of the sports pre-existed as mass sports. Some of the sports were military sports. Therefore, a special section or department was added to the local and provincial sports commission called 'military sports section/department'. Budgets and instructors were specially provided for this new development.

School physical education classes were now turned into military training courses. A primary school student in Santai County, Sichuan province recalled the military sports activities carried out in his school and home town in 1964:

'Promote Sport, Exercise the Body, Protect Our Country' was the slogan at that time....Some students in my school were selected to join the Red Scarf Shooting Team. I became a member of the team in 1965 and practiced shooting with sporting rifle twice a week. Most of the time, we practiced target shooting. Sometimes we were lucky enough to shoot used light bulbs with real bullets....There were shooting teams in secondary schools. One of my friends was a student in the secondary school. He was a 
member of the shooting team and they used real rifles....Their training also included formation drills, gymnastics, swimming, cross-country racing and mountain climbing.

... Santai County was very poor in the 1960s so there was no proper swimming pool. We had to swim in the Fujiang River....My father worked in the local government and he and his colleagues had to learn to swim in the river as part of the military training. I remember one day he returned home and told us that the head of the local government had almost drowned when they swan across a river. ${ }^{21}$

The militia men and women in factories and communes were taking a certain amount of time off from their work every week to undertake military sports. A poor peasant in the Red Flag Commune, Tongnan County of Sichuan province, recalled:

In our People's Commune 200-300 young men and dozens of young women between 18 and 25 years old were selected to be 'Backbone Militia.' Most of them were sons and daughters of poor peasants. They were equipped with rifles. In slack farming seasons they practised formation drills, running and shooting. I saw them learning to swim in the Fujiang River in the summer. ${ }^{22}$

To encourage more people to participate in military sport, Mao Zedong swam in the Ming Tombs Lake in Beijing accompanied by students from the Capital Normal University and soldiers from the People's Liberation Army (PLA) on 16 June 1964. While swimming Mao told the students and soldiers: 'Swimming is a good sport that challenges natural forces. You should swim in big rivers and the sea to train your mental and physical strength'. ${ }^{23}$ After Mao's symbolic swim the Sports Ministry and the PLA jointly issued 'Promoting Swimming among the Masses' in May 1965. It pointed out: 'Swimming can promote people's physique, and cultivate the spirit of bravery and tenacity. It is important for training masculine bodies for national defence $^{24}$. Also in May 1965, the Central Committee of the Chinese Communist Youth League issued a policy document 'Important Issues in Military Sport' to clarify nine key military sports: shooting, swimming, air defence, throwing, radio, camping, cross-country racing, mountain climbing and martial arts. It required all members of the Youth League and the Chinese youth to participate in the military sports listed in the document and to prepare for war. ${ }^{25}$

The number of registered militia reached 163.28 million in the early 1960s. Among the 4.56 million were the 'Backbone Militia'. ${ }^{26}$ All efforts were being made to serve national defence and prepare for war. As indicated in the 'Report on the 1965 National Sports Congress' published by the Central Government and the Sports Ministry on 15 May 1965:

Great efforts have been made to promote military sport. We have followed Mao Zedong Thought on People's War and serve the purpose of national defence. Our priority will be to continue to promote mass military sport, and to train the militia men and women in order to provide back-up force for national defence. ${ }^{27}$

Mao Zedong was pleased with the achievements of all the people who had become soldiers, especially the women in the militia. He wrote a poem 'For the Female Soldiers' (七绝·为女民兵题照) in 1965 which read:

Valiant heroines grasping rifle guns,

Morning twilight illuminating the drilling ground.

What a grand aspiration Chinese women taking on,

Favouring military uniform other than lady's costume. ${ }^{28}$ 


\section{Training communist champions}

While the whole country was becoming an army camp and ordinary people were being turned into soldiers, elite athletes faced more challenges. They were expected to be soldiers as well as athletes. They were taught to treat the sports fields as battlefields and their counterparts as enemies. They were expected to beat their enemies and win battles and wars at all costs since a sport competition was war without fire. In order to prepare them to win 'wars' the principle was 'Train the soldiers [athletes] at home and compete against the foreign competitors' (国内练兵, 一致对外). ${ }^{29}$

Learning from the PLA, a series of training philosophies were introduced to train masculine bodies for sports competitions. In March 1964 the Sports Ministry issued a Directive that required athletes to learn from the PLA. They were particularly required to learn the PLA's tradition of never fear hardship and death (see figure 1). ${ }^{30}$ In December 1964 the Sports Ministry's National Congress announced that athletic training should be copied directly from the PLA's training philosophy and methods. They were firstly: 'Three basic rules and one principle': this referred to understanding the complexity; the strictness; and the mentality of preparing for real battle; and principles of heavy and intensive training (三从一大). Secondly there were, 'Three fearless': meaning fearless of hardship, fatigue and difficulties (三不怕). Thirdly, there were 'Five commitments': meaning total commitment to political loyalty; to training of the body; to understanding technique; to tough and hard mental training; and to fierce competition' (五过硬).

Scientific training was not the concern here. Therefore, athletic training time was extended and exercise intensity increased. Furthermore, athletes were required to spend time living in the army barracks and undertaking military and physical training with the soldiers.

While the body was trained, the mind had also to be cultivated. The Communist champions must be loyal to the Party, commit themselves to political missions and achieve greater success for the country. The Sports Ministry issued 'Regulations for the Ideological and Political Education of Athletic Teams' in May 1964. This required sports governing bodies at all levels to establish departments for ideological and political education. The departments would be in charge of athletes' political education in subject areas including collectivism, patriotism and socialist/communist morality. Under the leadership of the departments, political instructors and teachers would be sent to all sports teams to help athletes to study Marxism, Leninism and Mao Zedong Thought and to understand current political affairs every week. The Regulations also required the athletes to work in the countryside, factories and military camps for 15 to 30 days per year. It believed that the peasants, workers and soldiers would teach them a work ethic and loyalty to the party.

In $1964 \mathrm{Xu}$ Yinsheng, a table tennis player, set a good example to all Chinese athletes. Xu captured the world title in the men's doubles at the World Table Tennis Championships in 1963. He was invited to give a talk to female table tennis players in September 1964 to help them to prepare for their forthcoming international competitions. During his two-hour talk, Xu vividly convinced the audience that it was Mao Zedong Thought, the 'Spiritual Atom Bomb', which had guided him to overcome all the hardships and difficulties and to achieve success. Xu's talk was published as an essay by the Ministry of Sport and distributed as compulsory learning material for all Chinese athletes, especially the athletes in national teams. 


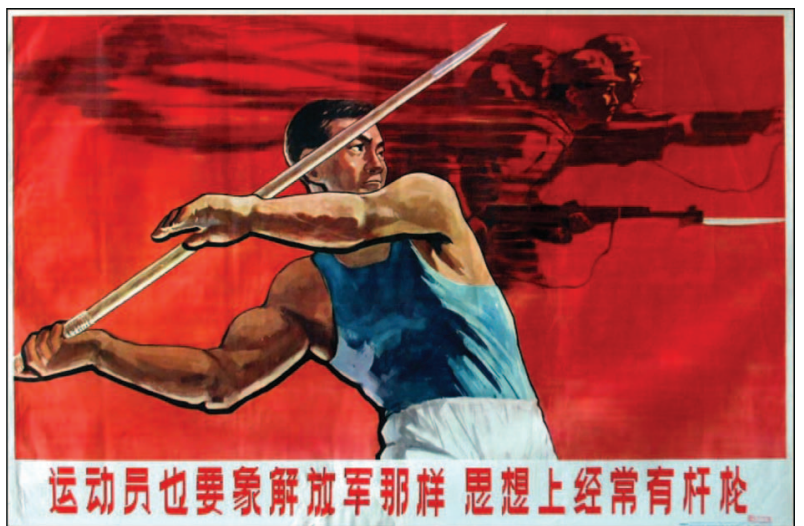

Figure 1. Sichuan People's Press. 'Athletes should learn from the People's Liberation Army and equip their minds with the right focus- like the direction of a rifle' (Poster). Chengdu: Sichuan People's Press, 1965.

Source: Sichuan People's Press, 1965. Available from: http://edu.cnr.cn/pic/jczt/200808/ t20080815_505070328.html

Mashal He Long also showed this essay to Mao Zedong in early January 1965. Mao was pleased with it and commented on 12 January 1965:

Comrade Xu Yinsheng's talk and Comrade He Long's comment should be printed and circulated among the comrades attending the Central Government's Work Conference. They should re-print and distribute it when they go back [to their ministries and departments]. Comrades, should we refuse to learn from this young fighter? The talk is based on dialectical materialism....I have not read anything as good for years. Although he talks about how to play table tennis what we can learn from it are theory, politics, economy, culture and military affairs. If we do not learn from this young athlete, we will be doomed soon. ${ }^{31}$

With Mao's endorsement, five days later, the People's Daily published Xu's essay on the front page and $\mathrm{Xu}$ found himself to be the role model not only for Chinese athletes, but also the general public. ${ }^{32} \mathrm{He}$ became as perfect a Communist champion as the Party could have hoped for.

\section{Standardisation of the sports elite system and structure}

During the first half of the 1960s there took place a process of standardisation of the system and structure of elite sport. The Sports Ministry issued the 'Regulations of Outstanding Athletes and Teams' in March 1963 to improve the elite sport system and management structure in order to enhance the level of performance. It listed 60 regulations in respect of training, competition, education, coaching, athletes, medical support, organisational structure, management and leadership. In May 1963 another policy document 'Inspection of the National Records and the Establishment of the Reward System' was issued. According to this, athletes would be awarded medals for their achievements by the Sports Ministry. ${ }^{33}$

Spare-time sports schools were a key reserve of talent for Chinese elite sport. The Sports Ministry issued the 'Regulations of Spare-time Sports Schools' in September 1964. It aimed to cultivate the young and talented. It stated that spare- 
time sports schools should be set up within the local and provincial sports commissions. The heads of the sports commissions were the heads of the sports schools. There would be different forms of sports schools, boarding, half-boarding and after school training, depending on the financial resources provided by the sports commissions. Full-time coaches and training facilities and grounds would be provided by the sports commissions. For boarding sports schools academic tutors would be employed.

In June 1965 the Sports Ministry again emphasised the significance of sports schools: 'Spare-time sports schools must be established throughout the country to provide elite athletes for professional athletic teams. Some provinces and autonomous regions may build selected sports schools into reserve teams for professional sports squads'. ${ }^{34}$ It was in favour of the sports boarding schools structure. It proposed that this kind of school would be able to offer half a day for academic work and half a day for sports training. In this way it was hoped that students would fully develop their sports potential as well as keeping up with their academic education.

With the standardisation of management structure, coaching, training and the education system, a three-layer pyramid was formally established with the spare-time schools at the bottom, the provisional sports teams in the middle and the national squads on the top.

The Sports Ministry at a national sport congress in January 1965 announced its goal was to let the ten key sports reach the world level in ten years time. The level of performance in 1965 was impressive: 189 national records were broken 1,177 times by 259 female athletes and by 239 male athletes ${ }^{35}$ (see figure 2); and 66 Chinese athletes broke world records of 28 events 41 times. $^{36}$

\section{The Second National Games in 1965}

The Second National Games was scheduled to take place in 1962. However, due to the recession and famine brought about by the Great Leap Forward (GLF), the Games did not happen until 1965 when the economy was gradually recovering. The country needed a national gathering to celebrate national unity, to demonstrate the development of military sport and its readiness for any possible war; and to show the level of elite sports. The Sports Ministry pointed out that the Games would 'Facilitate the development of mass sport, cultivate talented young athletes, improve

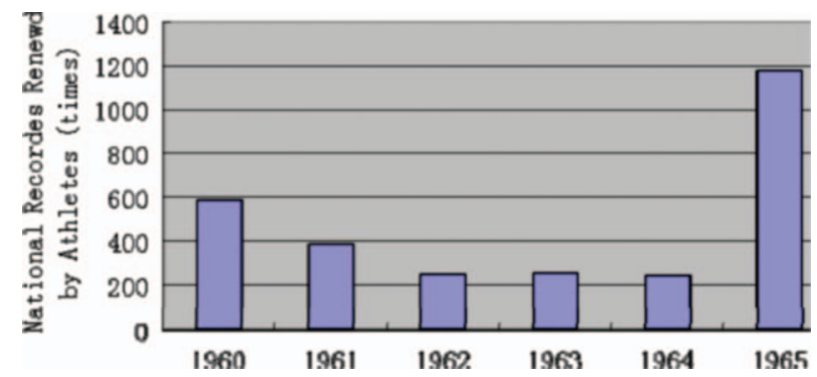

Figure 2. National records broken by athletes from 1960 to 1965 (times). Source: Figure developed by the author. 
the level of performance and thus enhance China's international status and political influence by achieving success at the New Emerging Force Games and other international sports competitions'. ${ }^{37}$

The Second National Games took place in Beijing on 11 September 1965. Altogether, 5,922 athletes (3,911 male and 2,011 female) from 28 provinces and the People's Liberation Army participated in 22 sports and 130 national records were broken 469 times by 331 athletes. ${ }^{38}$ The Games reflected the growing militarism and the slogan of the Games was 'Exercise the body; Build our Motherland, Defend our country'.

Mashal He Long highlighted the role of sport in national defence at the opening ceremony of the Games:

During the past 16 years, guided by the Party's and Chairman Mao's instructions, sport contributed to the promotion of people's physique, the construction of the country, national defense and served proletarian politics....People participated in swimming, shooting, radio sport and mountain climbing. They trained themselves for the purpose of protecting the mother country. They will be prepared to answer the mother country's call to beat American imperialists and their running dogs who dare to invade our country ... ${ }^{39}$

He praised the elite athletes who have fulfilled their political commitment:

During the past 16 years, our elite athletes have broken national records more than 5,700 times and world records more than 100 times. They have captured 13 world titles for the country....The Chinese Table Tennis Team has won great honour for the mother country by winning medals at the World Table Tennis Championships. The National Mountain Climbing Team has conquered the summit of Mount Everest. Our athletes have demonstrated the Chinese people's spirit of struggle. The Chinese people should learn from them. ${ }^{40}$

Lu Dingyi, head of the Propaganda Department of the CCP Central Committee, the powerful body in charge of all political publicity and the media in China, emphasised again, at the closing ceremony of the Games on 28 September 1965:

Recently, the United States is expanding the Vietnam War. India is invading Pakistan and continues to make troubles at the Sino-India border. Therefore, we must be alert and be prepared for War. Sport policy and practice must respond to the current situation. We must promote mass sport and military physical exercises. The aim is to mobilize all the Chinese people to exercise their bodies and their minds to defend our country. ${ }^{41}$

The group calisthenics, performed by 16,000 people at the opening ceremony, fully demonstrated the close relationships between sport, politics and militarism. ${ }^{42}$ The show was entitled 'Ode to Revolution'. It had seven scenes: 'The Prelude'; 'Raise the Revolutionary Torch'; 'Self-Reliance and Go All Out'; 'The People's Commune'; 'Hold the Gun Tightly'; 'The Red Successors' and 'Carry the Revolution on to the End'. The themes and performance were heavily coloured by class struggle, nationalism, militarism, socialism and communism. ${ }^{43}$

The Second National Games was portrayed by the Chinese media as a celebration for the country's achievements in sport since the GLF and a new starting point for Chinese athletes'campaign to reach the world level. ${ }^{44}$ In addition, the participation of hundreds of athletes from 28 minority ethnic groups was highlighted by the media and demonstrated national unity to the general public. ${ }^{45}$ 


\section{China, the Non-Aligned Movement and the 1962 Asian Games}

The world changed rapidly after the Second World War. The awakening of nationalism in the colonies of the western powers in Asia, Africa and Latin America gave birth to many independent nation states. In the 1940s and 1950s, 50 nations claimed independence. ${ }^{46}$ These newly emerging countries changed the landscape of world politics forever.

The PRC was a member of the socialist camp and, therefore, Chinese foreign policy in the 1950s focused on strengthening its relationship with the Soviet Union and other East European countries. It also focused on supporting national liberation movements in Asia, Africa and Latin America. It began to forge relationships with newly independent countries that had a similar historical background to China and it established foreign relations with some Asian countries including India (1950), Burma (1950), Vietnam (1950), Indonesia (1951) and Pakistan (1951).

The key milestone in the relationship between China and the emerging independent countries came in 1955 when the Asia-Africa Conference was held in Bandung under Indonesian leadership. The original suggestion that invitations be sent to the Afro-Asian members of the United Nations (UN) was now endorsed by India and Burma and was now extended to include other non-member countries such as Cambodia, the two Vietnams, the Gold Coast and China. The Soviet Union was not included despite its control of the Asian heartland. ${ }^{47}$

The conference took place in April 1955. The attendance of representatives of 29 countries at the conference was a considerable diplomatic success. Sukarno's speech at the opening of the conference began: 'This is the first inter-continental conference of coloured people in the history of mankind!'. He went on: 'Sister and Brothers, how terrific and dynamic is our time....Nations, States have awoken from sleeps of centuries....Hurricanes of national awakening and reawakening have swept over the land ...' ${ }^{48}$ But in spite of the wind of change, colonialism was still not dead and resistance to it was one of the things which bound together the nations represented at Bandung. Sukarno continued: 'For many generations out people have been the voiceless ones in the world. We have been the unregarded, the people for whom decisions were made by others whose interests were paramount, the peoples who lived in poverty and humiliation. Then our nations demanded, nay fought for independence, and achieved independence, and with that independence came responsibility'. ${ }^{49}$ The conference developed the sense of a common interest as nations standing apart from the great power blocs with shared experiences of domination under colonialism and it represented the underdeveloped countries.

By participating in the Bandung Conference, the PRC established a close relationship with the non-aligned countries. It was attempting to present a new image to the nations of Southeast Asia. The Chinese Premier Zhou Enlai was remarkably successful in conveying an impression of conciliation and reasonableness, saying he had come 'to seek unity and not to quarrel'. 50

However, for the United States, the conference was a challenge to the Southeast Asia Treaty Organization, which had been created in 1954 for collective defence against socialist countries in Southeast Asia. ${ }^{51}$ The United States' Central Intelligence Agency (CIA) condemned the conference as 'another example of Sukarno's fraternization with the Communist Chinese. He was 'in the process of selling his charisma, if not his soul, to the communists'. ${ }^{52}$ 
Following the Bandung Conference, Sukarno developed the concept of struggle between the Newly Emerging Forces and the Old Established Forces (the old forces of domination). In his address to the UN in September 1960 with the title 'To Build the World Anew', he argued that the real conflict in the world was not the cold war but that between imperialism in its new forms on the one hand and justice, quality and freedom for the long exploited peoples of the world on the other.

One year later, the first conference of heads of states of governments of nonaligned countries was held in Belgrade in September 1961. Indonesia had helped to sponsor it. The concepts of the New Emerging Forces and the Old Established Forces; and that the safety of the world was always threatened by the Old Established Forces were accepted by the conference. The Non-Aligned Movement (NAM) was formed in 1961. It was an intergovernmental organisation of states which aimed to ensure 'the national independence, sovereignty, territorial integrity and security of non-aligned countries'; and to 'struggle against imperialism, colonialism, neo-colonialism... and any form of foreign aggression, occupation, domination, interference or hegemony, as well as the struggle against the policies of big powers or blocs.'. ${ }^{53}$ Its aim was to unite all the developing countries in Asia, Africa and Latin America and it asserted equal rights with the Old Established Forces in aspects of national and regional interests (see Figure 3).

By 1961 the Sino-Soviet split had become obvious. China's foreign policy was to oppose USSR revisionism as well as US imperialism. ${ }^{54}$ The departure from the Soviet and East European camp urged China to grasp quickly the implications of the NAM in terms of its long-term potential impact on the non-aligned emerging states and the opportunity to create a new world structure in which China could play its role. Zhou Enlai wrote to the conference,

I would like to congratulate the conference on behalf of China. Furthermore, I wish the conference will contribute to Asian, African, and Latin American people's struggle for national independence, their struggle against invasion and interference by imperialism, their struggle against new and old colonialism, and their struggle for world peace. ${ }^{55}$

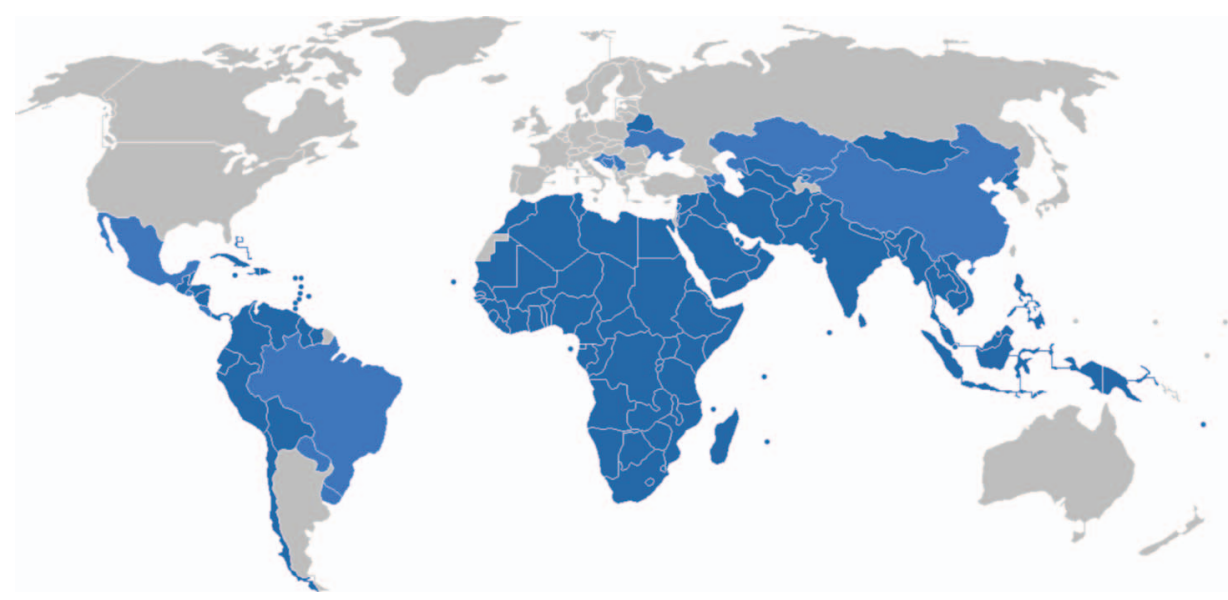

Figure 3. Member states of the non-aligned movement.

Source: Afrasiabi, K.L., available at: http://www.iranreview.org/content/Documents/Non_ Aligned_Movement_Backs_Iran.htm 
In return, the conference acknowledged the PRC as the only legitimate representative of China. It stated in the Declaration of the Heads of State of Government of Non-Aligned Countries:

Those of the countries participating in the Conference who recognize the Government of the People's Republic of China recommend that the General Assembly in its forthcoming Session should accept the representatives of the Government of the People's Republic of China as the only legitimate representatives of that country in the United Nations. ${ }^{56}$

Soon after the establishment of the NAM, sport became a battlefield of international politics between the eastern socialist bloc, the western capitalist bloc and the Newly Emerging Forces. It all began in 1962 when the Fourth Asian Games took place in Indonesia. The Asian Games had started in 1951 under the leadership of the Asian Games Federation (AGF). The purpose of the Games was to "promote the realisation of understanding and friendship among all nations and... start a process which, as time passes, will go on cementing the friendly ties between the peoples of Asia' ${ }^{57}$

The Games were recognised as a regional Games and were acknowledged by the International Olympic Committee (IOC). ${ }^{58}$ The Fourth Asian Games was to be held in Indonesia in 1962. At the time, President Sukarno had proclaimed himself the leader of the Bandung Conference and established himself as one of 'The Initiative of Five' of the NAM ${ }^{59}$ He looked on the Games as a means to strengthen his own position among the Newly Emerging Forces of Asia, Africa and Latin America that were 'struggling against capitalism and trying to create a new world order'. ${ }^{60}$ The PRC was a useful ally in this endeavour and was invited to join the Asian Games in Jakarta. The PRC also intended to use this opportunity to establish its position as a leader of the Newly Emerging Forces of the world.

However, there was a major obstacle. The PRC was not a member of the AGF. The Republic of China (Taiwan) was a founding member of the AGF and had represented China in the Asian Games in 1954 and 1958 respectively. ${ }^{61}$ According to AGF rules Taiwan would be entitled to participate in the 1962 Asian Games. Therefore, the Indonesian Embassy in Beijing informed the Chinese government at the end of 1961 that Jakarta would have to invite Taiwan to participate in the Fourth Asian Games and it consulted with Beijing on solutions.

The Chinese Sports Ministry listed four possible solutions for Indonesia: 1) Invite the PRC instead of Taiwan to represent China; 2) Not invite Taiwan or the PRC; 3) Invite Taiwan, but not recognise it as a country and, therefore, not raise its national flag at the Games; and 4) Invite Taiwan and accept Taiwan as a country. ${ }^{62}$

The second solution was seen as the most feasible one. Therefore, the Chinese Sports Ministry in Beijing and the Chinese Embassy in Jakarta began to convince Indonesia to adopt this solution. Premier Zhou Enlai and Foreign Minister Chen Yi both wrote to President Sukarno to persuade him to exclude Taiwan.

Nevertheless, the Jakarta organising committee sent an invitation letter on 1 March 1962 to Ho Geng-sheng (Hao Gensheng), who was a board member of the AGF and the representative of Taiwan, and invited him to attend a preparation meeting for the Fourth Asian Games in Jakarta in April 1962.

Beijing was not happy about this news. Although the PRC was not a member of the AGF it had had diplomatic relations with Indonesia since 1951. On 31 May 
the Chinese embassy in Jakarta sent a memo to the Indonesian government pointing out:

The Chinese government sincerely wishes that the Asian Games held by Indonesia will be a great success. But the Chinese government cannot ignore those imperialists and their followers who want to use the Asian Games to create 'two Chinas.' These activities will not only harm the friendship between the PRC and Indonesia, but also harm the stand of Indonesia's fight with imperialism. ${ }^{63}$

After careful consideration Indonesia decided not to invite Taiwan to attend the Games. At the same time, along with the protests of some Arab countries on the issue of Zionism, Indonesia decided not to issue visas to Israeli athletes either. ${ }^{64}$

The political action of Indonesia enraged the IOC and some international federations. They warned Jakarta that the Fourth Asian Games would face the sanction of not being recognised, as they could not tolerate a sports event mixed up with politics. The International Federation of Athletics announced that it would not recognise the results of track and field events at the games. The International Federation of Weightlifting asked its member states not to send athletes to the Games, otherwise the states' memberships would be suspended. ${ }^{65}$ Taiwan also protested against Jakarta's decision. Yan Zhengxing, head of the Taiwan Asian Games Delegation, stated publicly: 'I sincerely urge all athletes and sports organizations to uphold justice, disqualify Indonesia as the host of the Fourth Asian Games and refuse to acknowledge the Games'. ${ }^{66}$

Jakarta ignored the warnings from the IOC and the International Federations (International Federations). On 24 August 1962 the Foreign Minister of Indonesia formally announced that it would stick to its decision to reject Taiwan and Israel from participating in the Games. The IOC and the IFs immediately stated that they would not recognise the Games, since they could not tolerate such a political Games.

India was not happy with Indonesia's decision. ${ }^{67}$ India's relations with Indonesia had begun to experience a downturn in the early 1960s. Retzlaff pointed out that

Conflicting interests and aims had in several cases become increasingly apparent, vide India's opposition to Indonesia's attempts to convene a second Bandung Conference, and the negative response by many of the nations at the Belgrade Conference of nonaligned nations in 1961 to Prime Minister Nehru's plea that the issues of world peace and disarmament were of greater urgency than anti-colonialism. ${ }^{68}$

At the same time, the Sino-India border conflict had begun. The relationship between India and China deteriorated to its lowest point.

Against this background G.D. Sondhi from India, 'the Father of the Asian Games' who was also a member of the IOC, arrived in Jakarta on 3 September 1962 and publicly criticised Indonesia's rejection of Taiwan and Israel's participation in the Games. His criticism angered Indonesian nationalists and a demonstration took place outside the Hotel Indonesia in which Sondhi was staying. Retzlaff stated that 'An estimated 20,000 Indonesians stormed the Indian Embassy and sought to tear down the Indian flag'. 69

Finally, the Fourth Asian Games took place between 24 August and 4 September 1962 in Jakarta. Altogether, 1,460 athletes from 16 countries competed at the Games. Indonesian athletes performed very well and won 48 medals, including 21 gold medals. The Fourth Asian Games was a demonstration to the Jakarta populace of Indonesia's standing in the eyes of her neighbours. It secured for the nation a fine 
sports complex at Senayan and it excluded competitors from Taiwan and Israel despite the pressure from the old-established powers. It was a sign of the nation's greatness and of its independence. Although the PRC did not participate in the Games it had successfully lobbied for the exclusion of Taiwan from the Games, and so had shown its significant political and diplomatic influence on Indonesia and other NAM nation states.

\section{China and the GANEFO}

After the Fourth Asian Games, on 7 February 1963, the IOC decided to suspend the membership of the Indonesian Olympic Committee for an indeterminate period of time for not having protested against its government's discriminatory action against Taiwan and Israel. The IOC stated:

The IOC and the IFs [International federations] are completely opposed to any interference in sport on political, racial or religious grounds, and particularly any which prevents the unhindered passage of competitions and officials between their member countries. $^{70}$

Two days later, on 9 February, the Indonesian Sports Ministry responded with a strongly worded statement and a proposal of a new world games - the Games of the Newly Emerging Forces (GANEFO):

The exclusion of Indonesia from the Olympic Games will not harm Indonesia. On the contrary, Indonesia will now have the freedom to organize a new games without the participation of imperialists and colonialists. The new games is GANEFO - the Games of the Newly Emerging Forces - Asia, Africa, Latin America, and the socialist countries....It is time that the new emerging countries should have a revolution to destroy the spirit and structure of the international sports movement which is controlled by the imperialists and colonialists. ${ }^{71}$

Three days later, on 12 February, China declared its support and sent a congratulatory telegraph to the Indonesia Olympic Committee. ${ }^{72}$ The Arab League, which appreciated Jakarta's decision to exclude Israel from the Games, also requested its member states to support Indonesia and protest against the IOC. ${ }^{73}$

On 13 February 1963 President Sukarno announced that Indonesia would withdraw from the IOC and would hold a new world games, the GANEFO, to fight against the IOC. He even compared the significance of the GANEFO to the Indonesian Independent Movement against Dutch colonists between 1945 and 1949. ${ }^{74}$ Sukarno stated that in Indonesia sport was used to further the country's political aims, namely, world friendship and peace. For Sukarno and the PRC, the Olympic Games were but a tool of the old-established forces that engaged in discriminatory actions against Asian, African, and Latin American nations. Now these discriminated nations were going to use the GANEFO as a tool to oppose the old-established forces.

Jakarta and Beijing had begun to prepare for the GANEFO long before the IOC suspended Indonesia's membership. The idea had first appeared in Sukarno's speech responding to Sondhi's criticism in September 1962. He stated:

it is the view and attitude of the majority of the AGF, which is the representative of 13 nations that signed the convention of Asia-Africa Bandung Conference, that the Asian Games does not truly reflect the true spirit of Bandung. Right now, we will stage a new games among the New Emerging Forces, as soon as possible, yes, in $1963 .{ }^{75}$ 
The idea of hosting theGANEFO was released to the press in September 1962. It was immediately supported by Beijing. The Chinese government gathered experts from the foreign and sports ministries to analyse the feasibility of organising a new games. After careful study, they concluded that since the Second World War, the colonial and semi-colonial countries of Asia, Africa and Latin America had become independent, but that imperialist countries which dominated the IOC still denied their rights in international sports affairs. The new games, therefore, would attract those newly independent countries. At the same time the new games could provide a unique stage for the PRC to demonstrate its power over and influence on those countries.

Two months after the Fourth Asian Games, a Chinese sporting delegation visited Indonesia on 22 November 1962 to exchange views on the GANEFO. The PRC agreed to use its influence to persuade some Asian and African countries to join the Games. A special research department was set up to advise Indonesia on the GANEFO.

Liu Shaoqi, Chairman of the PRC, visited Indonesia in April 1963 and signed with Sukarno a joint declaration that accused the IOC and reaffirmed that China would support the GANEFO: 'The Chinese government condemns the IOC's arbitrary decision to exclude Indonesia from the Olympic Games. The Chinese Government strongly supports the GANEFO proposed by President Sukarno and will make best efforts to contribute to the GANEFO'. ${ }^{76}$ Although China was still suffering the economic crisis brought by the Great Leap Forward, the Chinese government helped to build new stadiums in Jakarta and donated sports facilities and equipment for the GANEFO. ${ }^{77}$

A preparatory conference for the GANEFO was held in Jakarta in April 1963. The PRC, Cambodia, Guinea, Indonesia, Iraq, Mali, Pakistan, North Vietnam, the United Arab Republic (Egypt) and the Soviet Union were present. Ceylon and Yugoslavia sent observers. The aim of the GANEFO was agreed: 'The Games was to be "based on the spirit of the 1955 Bandung Conference and the Olympic ideals, and was to promote the development of sport in new emerging nations and to cement friendly relations among them"". 78 At the conference, an organising committee for the Games was established. Indonesia was elected to be the chair country. China, the United Arab Republic and the Soviet Union became the chair countries of Asia, Africa and Europe. The conference declared that the GANEFO would be held every four years in Third World countries. The first Games would take place in Jakarta in November 1963. All the Newly Emerging Forces would be invited to join the GANEFO.

Although the IOC and many IFs, including The Fédération Internationale de Football Association (FIFA), the Fédération Internationale de Natation (FINA), the International Association of Athletics Federations (IAAF) and the International Weightlifting Federation (IWF), warned their members not to send teams to the GANEFO in June 1963, 48 countries from Africa, Asia, Europe, and Latin America participated in the Games, which commenced on 10 November 1963. The Games lasted for 12 days and 2,404 athletes competed in 20 events. Badminton was the national sport of Indonesia and when the badminton men's singles final took place between China and Indonesia, it became a diplomatic game. When the Chinese player kept ahead and was about to defeat the Indonesian player, considering the Sino-Indonesia relations and the booming Indonesian nationalism, Marshal $\mathrm{He}$ Long, head of the Chinese sports delegation, immediately instructed the Chinese player to lose to his opponent. The Indonesian player won the gold medal and the victory greatly pleased the Indonesian people. ${ }^{79}$ 
By the time of the GANEFO, the Sino-Soviet split had taken place, dividing the Communist camp and creating three power blocs - the United States and Western Europe, the Soviet Union and Eastern Europe, and the PRC - each striving for the support of the non-aligned emerging states. The Soviet Union provided some financial support and participated in the GANEFO. However, in order not to jeopardise its stature in the Olympic movement, Moscow did not send its first class Olympic calibre athletes to the Games. ${ }^{80}$ In contrast, the PRC sent its 229 best athletes to the Games. It also provided strong political, financial, and organisational support to the GANEFO and it was a key force in facilitating the success of the Games.

After the Games, Chairman Liu Shaoqi and Premier Zhou Enlai sent a congratulatory telegram to President Sukarno. It praised the GANEFO as 'a great victory of the newly emerging countries against the imperialism and new colonialism's control over international sport' ${ }^{81}$ The GANEFO was also an inspiration to many Third World countries. It was seen as a victory against the Western powers. ${ }^{82}$ Camara Mamadi, the head of the Guinea delegation commented:

The development of sports and relations of friendship and solidarity among the new emerging forces contributed in our opinion to the quest for world peace and, likewise in the GANEFO- a positive contribution and original manifestation to the struggle against colonialism and imperialism. ${ }^{83}$

Kim Ki Soo, head of the North Korea delegation stated that:

... the imperialists and the old forces of all hues have eventually failed in their intrigues to prevent the peoples of the New Emerging Forces attending their all friendly games. They have also failed to be an obstacle in the meeting of the delegates from the countries of the New Emerging Forces....The government of the Democratic People's Republic of Korea (PDRK) has actively supported the ideals of the GANEFO....The delegation of the Democratic People's Republic of Korea calls for developing an independent sport movement of the peoples of the New Emerging Forces, completely free from imperialism and colonialism and from the influence of the old forces of all hues. ${ }^{84}$

The GANEFO posed a real threat to the IOC and challenged its hegemony in the Third World. During the Games a council consisting of 36 member countries was established. It proposed that GANEFO Continental Committees should be established in Asia, Africa, Europe, America and Australasia, and that the 36 member countries should have their own national GANEFO committees. ${ }^{85}$ Its intention was to create a new order in world sport. Brundage, the President of the IOC, voiced this fear in a letter to the Marquess of Exeter, the President of the International Amateur Athletic Federation, the most important and influential international federation. With regard to the 'Africa Games' proposed by some African countries, he wrote:

If we want to hold the Olympic world together we must not let these 37 countries be led into the GANEFO camp, which may easily happen. Peking [Beijing], China is very active now in Africa and Congo Brazzaville has recently received from it a $\$ 20,000,000$ loan. The Egyptians are organising the second GANEFO Games in Cairo in 1967 . . the Indonesian Embassy in Switzerland is inviting the National Federations and the Swiss NOC [National Olympic Committee] to the reception on the anniversary of the First GANEFO Games. This is probably also taking place in other places. The Arab countries and a few others are sympathetic... We... will probably drive them all into the receptive arms of the GANEFO crowd if we are not most careful. ${ }^{86}$ 
To conclude, the GANEFO movement intended to divide and fragment the Olympic movement, to emphasise the political realities of the new world structure. The aim of the GANEFO was 'to build a world anew, free from colonialism and imperialism in all their forms and manifestations. ${ }^{87}$ Its cCharter sums it up:

To develop a community of nations imbued with the spirit of the Asian-African Conference in Bandung in 1955 which ensures respect for each other's national identity and national sovereignty, strengthens friendship, and fosters cooperation towards lasting peace among nations and towards the Brotherhood of Man....Therefore, it will encourage and promote an independent development of sports and physical culture and sports movements in all countries of the Newly Emerging Forces. It will stimulate sporting cooperation among the youth of the Newly Emerging Forces in order to foster and consolidate friendly relations among them in particular and to promote amity and world peace in general. ${ }^{88}$

The GANEFO provided the best stage for the PRC to project its image, to extend its influence, to unite with Third World countries and to enable it to compete with the two power blocs: the Soviet Union and Eastern Europe, and the United States and Western Europe. Through the successes achieved at the Games, both in terms of sport and diplomacy, the PRC established its leadership in the Newly Emerging Forces and greatly reinforced its power and status in international politics. As the Sports Minister He Long concluded,

International sports exchanges have promoted mutual understanding and friendship between the peoples of China and many foreign countries. Together with the peoples in third world countries, we created the GANEFO which successfully broke the monopoly of the imperialists in international sport and promoted sport among the newly emerging forces. ${ }^{89}$

After the First GANEFO, Beijing took the leading position in organising the subsequent Games and grasped the opportunity to expand its influence in Asia, Africa and Latin America through sport. The Second GANEFO was scheduled to take place in Cairo, Capital of the United Arab Republic, in 1967, with Beijing as an alternative site. However, the United Arab Republic requested Beijing to donate a stadium for the second games. The request was discussed at the Ten Year Anniversary of the 1955 Bandung Conference, which was held in Jakarta in May 1965, between the Secretary-General of the Chinese Sports Ministry, Huang Zhong and representatives from the United Arab Republic, but failed to reach an agreement. ${ }^{90}$ The amount of donation that Cairo requested was equal to the value of the Algiers Conference Complex that China had donated for the Second AsianAfrican Conference which was planned to be held in Algeria in $1965 .^{91}$ Zhou Enlai discussed the issue with the United Arab Republic at the Asian-African leader's summit in Cairo in June 1965. Due to financial constraints both parties agreed to move the Second GANEFO to Beijing in $1967 .{ }^{92}$ The Capital Indoor Stadium was built for this purpose. ${ }^{93}$

Furthermore, in order to reinforce its influence in Asia, a plan to host an Asian edition of GANEFO came into being. In September 1965 the second session of the council of the GANEFO was held in Beijing, with 39 delegations present. A GANEFO Asian Committee was formed. Beijing played a major role in its formation and a Chinese official became the chairman of the executive committee of the GANEFO Asian Committee. A proposal for an Asian GANEFO was approved and it was to take place in Cambodia in 1966. It was 
designed to compete against the IOC backed Asian Games which would also take place in 1966.

The aim of the Asian GANEFO was to reinforce China's leadership in the Third World and to challenge American and Soviet powers. Chairman Mao, with his idea of the leadership of "World Revolution" in mind, wrote to the Games in December 1966: 'The struggle against imperialist America and its running dogs carried out by people all over the world will achieve greater success' (see Figure 4).

The Asian GANEFO was underwritten in large measure by the PRC. As in China's other diplomatic projects, for example the Algiers Conference Complex built for the 1965 Second Asian-African Conference and the TAZARA Railway Project for Tanzania and Zambia, the Chinese government helped build infrastructure in the form of a sports stadium with 50,000 seats as well as other facilities in Phnom Penh, the capital of Cambodia. It also helped train 300 referees for the games in five months. ${ }^{94}$ With the support of Norodom Sihanouk, the king of Cambodia, the Games were successfully held between 25 November and 6 December 1966, virtually simultaneously with the Fifth Asian Games which took place in Bangkok between 9 and 20 December 1966, from which the PRC was excluded and Taiwan included. Seventeen countries and regions with more than 2,000 athletes participated in the

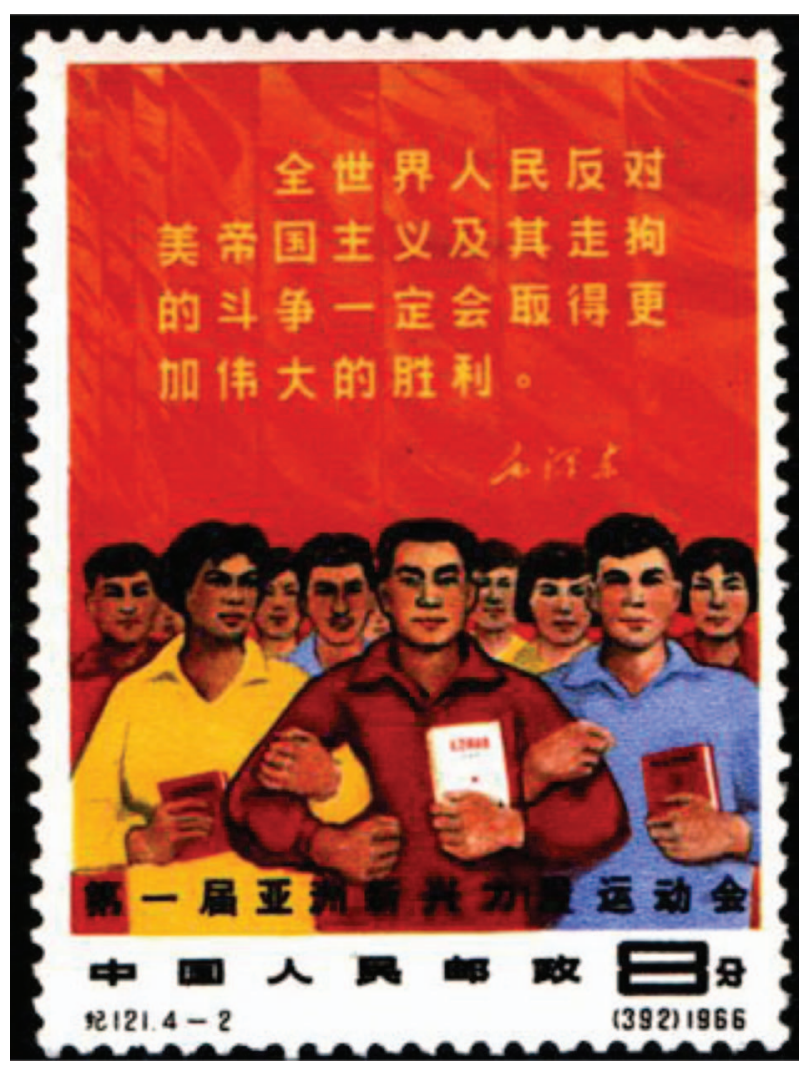

Figure 4. Commemorative stamp published by the PRC for the Asian GANEFO (published on 31 December 1966).

Source: http://tupian.hudong.com/a1_53_92_01300000397019132239923516457_jpg.html 
Asian GANEFO. Chinese athletes competed in 18 sports events, won 133 gold medals and broke two world records. ${ }^{95}$

However, despite the successful Asian GANEFO, the GANEFO was approaching its end. In West Asia, the United Arab Republic was not able to host the games as planned, due to financial problems. In Southeast Asia, Indonesia, the founder of the GANEFO, turned its back on China after Sukarno's regime was overthrown by General Suharto who was backed by the United States. ${ }^{96}$ In Northeast Asia, China, the major sponsor of the Games, was entering the turmoil of the Cultural Revolution and did not have the time and energy to look after the Games. The Second GANEFO, which was scheduled to be held in Beijing in 1967, died quietly.

\section{Conclusion}

Sport in the first half of the 1960s was strongly influenced by the government's policy of 'preparation for war' and 'eight million people eight million soldiers'. Threatened by foreign powers from Asia and the West, national security and defence became the priority of the country. Sports served the purpose of training masculine bodies for the war and sport was militarised.

On the other hand this period saw close relationships between sport and China's foreign diplomacy. Sport began to serve the PRC's foreign policy which focused on uniting the newly independent countries in Asia, Africa and Latin America to compete against the two world superpowers: the United States and the Soviet Union. In the 1950s and first half of the 1960s, the CCP leadership allied with the NAM member states to use the Fourth Asian Games and the GANEFO to win support from, and to build up its position in, the Newly Emerging Forces. The Games helped to implement China's foreign policy to establish and consolidate friendly relations with many Asian, African and Latin American countries. Consequently, China successfully established its position as a leading power in the Third World and changed the political landscape of the world which had mainly been shaped by the western capitalist bloc led by the United States and the eastern socialist bloc led by the Soviet Union. However, all the efforts devoted to building China into a world power were suspended when the Cultural Revolution started in 1966.

\section{Notes}

1. Maxwell, India's China War.

2. Calvin, The China-India Border War (1962).

3. Ibid

4. U.S. Department of State, 'China, October 1971-February 1972'; Prasad, Sinha, and Athale, History of the Conflict with China, 1962.

5. In the eastern sector, the Chinese withdraw their troops 20 kilometres from the McMahon Line. In the middle and western sectors, the Chinese frontier guards also withdrew 20 kilometres from the line of actual control. See Wang, A Critical Review of the Sino-Indian Relations of the Present Age.

6. Maxwell, India's China War, 226.

7. Liu, History of the Cold War.

8. On 21 July 1958, Pavel Yudin, the Soviet ambassador, proposed to Mao to build a joint submarine fleet. Mao rejected the proposal and said that the USSR's real objective was to control China's coastline; when the Great Leap Forward was launched by Mao in 1958, the CPSU criticised the movement. The criticisms sparked another wave of antiSoviet sentiment in China; on 23 August 1958, the PLA in Fujian province began to shell 
the Jinmen Island controlled by the Republic of China (Taiwan). The shelling lasted for more than 10years until China and the United States established formal diplomatic relations in January 1979. The USSR leaders were enraged by this military operation because the PRC did not inform them beforehand. See Luthi, The Sino-Soviet Split.

9. Cui, Conflict between China and the Soviet Union.

10. Liu, The History of Cold War.

11. Ibid.

12. Cui, Conflict between China and the Soviet Union; Luthi, The Sino-Soviet Split.

13. J. Chen, Mao's China and the Cold War.

14. This included 320 million RMB of aid, 270,000 guns, over 10,000 pieces of artillery, 200 million bullets, 2.02 million artillery shells, 15,000 wire transmitters, 5,000 radio transmitters, over 1,000 trucks, 15 planes, 28 naval vessels and 1.18 million military uniforms. See Li and Hao, The People's Liberation Army in the Cultural Revolution, 408-409.

15. Qiang, China and the Vietnam Wars, 1950-1975.

16. Ibid., 133

17. Han and Tan, Military Affairs in Contemporary China.

18. $\mathrm{Ke}, \mathrm{Li}$, and Haosheng Zhang. The People's Liberation Army during the Cultural Revolution. Beijing: Chinese Communist Party Literature Press, 1989.

19. He, "The Origins of the Slogan "Turn Everyone into A Soldier".

20. Ibid

21. Interview of Lu Weiping (Professor, Mianyang City, Sichuan Province, China) by the author, 5 March 2010.

22. Interview of Li Yuangui (Farmer, Great Buddha Village, Chongqing, China) by the author, 6 December 2009.

23. Zhi Wang and Lequan Cui, 'Mao Zedong and Sport', People's Liberation Army Daily, 28 December 2009.

24. The Sports Ministry and the PLA. 'Notification of Promote Swimming for the Masses', 1 .

25. Shandong Sports Commission, 'Major Events in Sport in Shandong Province between 1960 and 1969', Shandong Sports Commission, http://www.sdty.gov.cn/NewsView. aspx?NewsID $=$ BmpuBW6ptZI $=\&$ LinkId $=$ fJaqe $\% 2 B 21 \mathrm{Kmk}=($ accessed 14 November 2010).

26. Editorial Team of the Biography of Xu Xiangqian, The Biography of Xu Xiangqian.

27. Sports Ministry, 'Minutes of the National Working Conference of the Sports Ministry', 14 May 1965, Chinese Communist Party Literature Archive in Beijing, 1.

28. Mao, 'For the Female Soldiers', 19.

29. Ten sports were identified by the Sports Ministry as key sports. They were: basketball, volleyball, soccer, table tennis, track and field, gymnastics, weightlifting, swimming, skating and shooting.

30. Wang Jinxi was a worker at the Daqing Field, the largest oilfield in China. He led the No. 1205 drilling team. Despite fatigue, injuries and difficulties, Wang and his team kept working hard and successfully brought Daqing's first production well into operation in 1960. Wang was honoured by his colleagues as the 'Iron Man'. The government called the whole nation to learn from Wang's spirit of working hard and made him a role model for workers, peasants and students. In 1968, he was elected to be a member of the Ninth Central Committee of the CCP.

31. H. Chen, He Long and Xu Yinshen, 8.

32. Literature Research Center of the Central Government, Sport in the People's Republic of China - 100 Interviews.

33. The Sports Ministry, 'Inspection of the National Records and the Establishment of the Reward System'.

34. Wu, The History of Sport of the PRC, 129.

35. Editorial Team of the Yearbook of Chinese Sport, Yearbook of Chinese Sport (1963).

36. Ibid.

37. Sports Ministry, 'The Sports Ministry's Proposal to Host the Second National Games', 883.

38. Editorial Team of the Yearbook of Chinese Sport, Yearbook of Chinese Sport (19491991), Vol. 1. 
39. He, 'He Long's Speech at the Opening-Ceremony of the Second National Games', 84.

40. Ibid.

41. Guo, 'The Second National Games, Paean for the Revolution', 138.

42. General Administration of Sport of the People's Republic of China and Organizing Committee of the $10^{\text {th }}$ National Games of the People's Republic of China, The 10 National Games of China.

43. 'Group Calisthenics at the Second National Games'.

44. 'Exhibition on the Achievements in Sport'.

45. 'Achievements in the Second National Games'.

46. Stavrianos, The World Since 1500.

47. Legge, Sukarno - A Political Biography.

48. Dennehy, 'The Bandung Conference', 302.

49. Leifer, Dictionary of the Modern Politics of South-East Asia, 63.

50. Anwar, 'Indonesia and the Bandung Conference: Then and Now', 187.

51. The Southeast Asia Treaty Organization was designed to be a Southeast Asian version of the North Atlantic Treaty Organization (NATO). Membership of this organisation was restricted to pro-western nations including Australia, France, New Zealand, Pakistan, the Philippines, the Republic of China (Taiwan), Thailand, the United Kingdom and the United States. South Korea and South Vietnam were dialogue partners of NATO.

52. Anwar, 'Indonesia and the Bandung Conference: Then and Now', 187.

53. Willetts, The Non-Aligned in Havana: Documents of the Sixth Summit Conference and an Analysis of Their Significance for the Global Political System, 85.

54. Zhang, Review and Analysis of China's Foreign Relations (1949-2009).

55. CCCPC (the Central Committee of Communist Party of China) Literature Research Office in the Ministry of Foreign Affairs of People's Republic of China, Selected Works of Zhou Enlai, 310.

56. 'Belgrade Declaration of Non-Aligned Countries', 6 September 1961 http://www.nam egypt.org/Relevant $\% 20$ Documents $/ 01$ st $\% 20$ Summit $\% 20$ of $\% 20$ the $\% 20$ Non-Aligned $\% 20$ Movement\%20-\%20Final\%20Document\%20(Belgrade_Declaration).pdf (accessed 14 March 2011). Ministry of Foreign Affairs - Egypt.

57. Ministry of Youth Affairs \& Sports, '1st Asian Games 1951', http://yas.nic.in/ writereaddata/linkimages/3881395440.pdf (accessed 3 January 2012). Ministry of Youth Affairs \& Sports in India.

58. In the late 1940s, many western colonies in Asia became independent nation states. Thereafter, the will to host an Asian version of the Olympic Games emerged. During the 14th Olympics in London in 1948, Indian IOC representative Guru Dutt Sondhi communicated with other Asian representatives and raised the idea of holding the regional games in Asia. Consequently, the Asian Games Federation was established in February 1949 to organise the Asian Games. The First Asian Games was held in New Delhi, Capital of India, in 1951. The second and third Games took place in Manila and Tokyo in 1954 and 1958.

59. The founding fathers of the NAM were: Sukarno of Indonesia, Nehru of India, Josip Broz Tito of Yugoslavia, Gamal Abdul Nasser of Egypt and Kwame Nkrumah of Ghana. They were known as 'The Initiative of Five'.

60. Fan and Xiong, 'Communist China', 327.

61. Ibid.

62. Liang, He Zhengliang and the Olympics.

63. Sports Ministry, Minutes of the 1st GANEFO.

64. Fan, 'Communist China and the Asian Games 1951-1990'.

65. Liang, He Zhengliang and the Olympics.

66. Tang, China at the Olympic Games, 199.

67. India's relations with the NAM nations began to deteriorate. Conflicting interests became apparent in the early 1960s when India opposed Indonesia's attempts to convene the second Bandung Conference.

68. Retzlaff, 'India: A Year of Stability and Change', 100.

69. Ibid.

70. Senn, Power, Politics and the Olympic Games, 129. 
71. Ren, The New Flag in International Sport, 16.

72. Fu, The History of Sport in China, Vol. 5, 1949-1979.

73. The Arab League is a regional organization of Arab states in Southwest Asia, and North and Northeast Africa which was formed in Cairo in 1945. The founding members of the League were Egypt, Iraq, Jordan, Lebanon, Saudi Arabia and Syria. The main goal of the League is to safeguard the interests of Arab countries. By 2010, it has 22 members and four observers.

74. The Indonesian National Revolution took place after Indonesia's declaration of independence in 1945 and ended with Netherlands'recognition of Indonesia's independence in 1949. The Revolution destroyed the Dutch colonial administration.

75. 'GANEFO: Kelahiran dan Perkembangannya' [GANEFO: its Birth and Development'] (Jakarta: komite Nasional GANEFO, Release No. 2, 193), 8.

76. Editorial Team of the Yearbook of Chinese Sport, Yearbook of Chinese Sport (19491994), 39.

77. Fu, The History of Sport in China.

78. Espy, The Politics of the Olympic Games, 81.

79. Liang, He Zhengliang and the Olympics.

80. Ibid.

81. 'Cheer for the Opening of the First GANEFO', People's Daily, 10 November 1963.

82. Lutan and Fan, 'The Politicization of Sport'.

83. 'Document of the First GANEFO Congress', cited in Lutan and Fan, 'The Politicization of Sport: GANEFO - A Case Study', 26.

84. Lutan and Fan, 'The Politicization of Sport', 32.

85. Baoli Sun, 'The GANEFO', Tiyu Weekly, no. 5 (1999)

86. Lutan, and Fan, 'The Politicization of Sport', 33.

87. GANEFO Federation Permanent Secretariat, GANEFO, Its Principles, Purposes and Organisation, 30 .

88. Ibid.

89. He, 'He Long's Speech at the Opening-Ceremony of the Second National Games', 85.

90. Liang, He Zhengliang and the Olympics.

91. The conference was cancelled due to the political unrest in Algeria.

92. Liang, He Zhengliang and the Olympics.

93. Ibid.

94. In order to consolidate its relationship with Third World countries in Africa and win their support in international politics, the PRC decided in 1965 to build The TAZARA Railway to connect Tanzania and Zambia. The railway was built between 1970 and 1975 and was financed and executed by the PRC.

95. Three days later, the Fifth Asian Games were held in Bangkok and about 1,945 athletes from 18 countries participated.

96. The coup took place in Indonesia on 30 September 1965. It was a military operation planned by the right-wing Indonesian military and the United States. Militants assassinated six Indonesian Army Generals and controlled part of Jakarta. After they controlled the media outlets in the city, they claimed themselves to be communists. The coup was put down by General Suharto. Suharto then condemned the Indonesian Communist Party (PKI) for the rebellion and began to arrest communist members in Indonesia. It led to the purge of more than 300,000 Indonesian Communists. Between 500,000 and one million people, including many Indonesian Chinese, were killed. Subsequently, the politically weakened Sukarno was outmanoeuvred by General Suharto who was officially appointed the President in March 1968. See Scott, 'The United States and the Overthrow of Sukarno'; and Cribb, 'Unresolved Problems in the Indonesian Killings of 1965-1966'.

\section{References}

Afrasiabi, K.L. 'Non-Aligned Movement Backs Iran'. Iran Review. Available at: http:// www.iranreview.org/content/Documents/Non_Aligned_Movement_Backs_Iran.htm

Calvin, James Barnard. The China-India Border War (1962). Quantico: Marine Corps Command and Staff College, 1984. 
CCCPC (the Central Committee of Communist Party of China) Literature Research Office in the Ministry of Foreign Affairs of People's Republic of China, ed. Selected Works of Zhou Enlai. Beijing: Central Party Literature Press, 1990.

Chen, Hao. 'He Long and Xu Yinshen'. The Journal of the History of the Communist Party, no. 8 (2008): 8.

Chen, Jian. Mao's China and the Cold War. Chapel Hill: The University of North Carolina Press, 2000.

Cribb, Robert. 'Unresolved Problems in the Indonesian Killings of 1965-1966', Asian Survey, no. 42 (2002): 550-563.

Cui, Qi. Conflict between China and the Soviet Union. Beijing: People's Daily Press, 2009.

Dennehy, Kristine. 'The Bandung Conference'. In Pan-Asianism: A Documentary History: 1920-Present, ed. Sven Saaler and Christopher W.A. Szpilman, 299-306. Plymouth: Rowman \& Littlefield Publishers, Inc.

Editor. 'Achievements in the Second National Games'. In Yearbook of Chinese Sport (1965), ed. Editorial Team of the Yearbook of Chinese Sport, 87-90. Beijing: People's Sport Press, 1965.

Editor. 'Exhibition on the Achievements in Sport'. In Yearbook of Chinese Sport (1965), ed. Editorial Team of the Yearbook of Chinese Sport, 90-91. Beijing: People's Sport Press, 1965.

Editor. 'Group Calisthenics at the Second National Games'. In Yearbook of Chinese Sport (1965), ed. Editorial Team of the Yearbook of Chinese Sport, 90. Beijing: People's Sport Press, 1965.

Editorial Team of the Biography of Xu Xiangqian, ed. The Biography of Xu Xiangqian. Beijing: Contemporary China Press, 2007.

Editorial Team of the Yearbook of Chinese Sport, eds. Yearbook of Chinese Sport (1963). Beijing: People's Sport Press, 1965.

Espy, Richard. The Politics of the Olympic Games. Berkeley: University of California Press, 1979.

Fu, Yannong, ed. The History of Sport in China. Vol. 5, 1949-1979. Beijing: People's Sport Press, 2007.

Ganefo Federation. Permanent Secretariat, ed. GANEFO, Its Principles, Purposes and Organisation. Djakarta: Permanent Secretariat of the GANEFO Federation, 1965.

General Administration of Sport of the People's Republic of China and the Organizing Committee of the 10th National Games of the People's Republic of China, ed. The 10 National Games of China. Beijing: People's Sport Press, 2006.

Guo, Lei. 'The Second National Games, Paean for the Revolution'. China Sport, no. 2 (2009): $138-139$.

Han, Huaizhi and Jingqiao Tan. Military Affairs in Contemporary China. Vol. 1. Beijing: China Social Science Press, 1989.

He, Libo. 'The Origins of the Slogan "Turn Everyone into Soldier"'. Martial Historical Facts, no. 4 (2006): 11-17.

He, Long. 'He Long's Speech at the Opening-Ceremony of the Second National Games'. In Yearbook of Chinese Sport (1965), ed. Editorial Team of the Yearbook of Chinese Sport, 84-85. Beijing: People's Sport Press, 1965.

Kaveh, L.Afrasiabi. 'Non-Aligned Movement Backs Iran', Iran Review, http://www.iran review.org/content/Documents/Non_Aligned_Movement_Backs_Iran.htm (accessed 18 September 2010).

$\mathrm{Ke}, \mathrm{Li}$, and Haosheng Zhang. The People's Liberation Army during the Cultural Revolution. Beijing: Chinese Communist Party Literature Press, 1989.

Legge, D.John. Sukarno - A Political Biography. Singapore: Archipelago Press, 1972.

Leifer, Michael. Dictionary of the Modern Politics of South-East Asia. London: Routledge, 1996.

Li, Ke and Shengzhang Hao. The People's Liberation Army in the Cultural Revolution. Beijing: The History of Chinese Communist Party Press, 1989.

Literature Research Center of the Central Government, ed. Sport in the People's Republic of China - 100 Interviews. Kunming: Guizhou People's Press, 2008.

Liu, Jinzhi. The History of Cold War. Beijing: World Affair Press, 2003.

Luthi, M. Lorenz. The Sino-Soviet Split: Cold War in the Communist World. Princeton, NJ: Princeton University Press, 2008. 
Lutan, Rusli and Fan Hong. 'The Politicization of Sport: GANEFO - A Case Study'. In Sport, Nationalism and Orientalism: The Asian Games, ed. Fan Hong, 22-36. London: Routledge, 2006.

Mao, Zedong. 'For the Female Soldiers'. In Mao Zedong's Poems, ed. China Literature Press, 19. Beijing: China Literature Press, 1991.

Maxwell, Neville. India's China War. New York: Pantheon Books, 1970.

Prasad, S.N., P.B. Sinha, and A.A. Athale, ed. History of the Conflict with China, 1962. New Delhi: Ministry of Defence, Government of India, 1992.

President Rajendra Prasad's (India's first President) speech at the opening ceremony of the Games on 4th March 1951, 1st Asian Games 1951.

Qiang, Zhai. China and the Vietnam Wars, 1950-1975. Chapel Hill: The University of North Carolina Press, 2000.

Ren, Dan. The New Flag in International Sport. Beijing: People's Sport Press, 1963.

Retzlaff, J. Ralph. 'India: A Year of Stability and Change'. Asian Survey 3, no. 2 (1963): 96106.

Scott, Dale Peter. 'The United States and the Overthrow of Sukarno, 1965-1967'. Pacific Affairs, no. 58, 1985: 239-264.

Sichuan People's Press. 'Athletes should learn from the People's Liberation Army and equip their minds with the right focus- like the direction of a rifle' (Poster). Chengdu: Sichuan People's Press, 1965.

Senn, Alfred. Power, Politics and the Olympic Games. Champaign, IL: Human Kinetics, 1999.

Sports Ministry, ed. Minutes of the 1st GANEFO, 1963. National Sports Bureau Archives, Sports Ministry, Beijing.

Sports Ministry. 'The Sports Ministry's Proposal of Hosting the Second National Games'. Collection of Sports Policy Documents. Beijing: Beijing People's Press, 1982, 883.

Stavrianos, L.S. The World Since 1500: A Global History. New York: Prentice Hall, 1966.

Sun, Baoli. 'The GANEFO', Tiyu Weekly, no. 5 (1999): 6.

Tan, Hua, ed. The History of Sport. Beijing: Higher Education Press, 2005.

Tang, Minxing. China at the Olympic Games. Vol. 2. Taipei: Chinese Taipei Olympic Committee Press, 2000.

The Sports Ministry. 'Inspection of the National Records and the Establishment of the Reward System', May 1963. National Sports Archives, the Sports Ministry, Beijing.

The Sports Ministry and the PLA. 'Notification of Promote Swimming for the Masses', 14 May 1964. National Sports Archives, the Sports Ministry, Beijing.

US. Department of State. 'China, October 1971-February 1972' (Declassified). Foreign Relations, 1969-1976, Volume XVII (Declassified).

Wang, Hongwei. A Critical Review of the Sino-Indian Relations of the Present Age. Beijing: China Technology, 2009.

Willetts, Peter. The Non-Aligned in Havana: Documents of the Sixth Summit Conference and an Analysis of Their Significance for the Global Political System. New York: St. Martin's Press, 1981.

Wu, Shaozu, ed. The History of Sport of the PRC. Beijing: China Book Press, 1999.

Zhang, Yunling. Review and Analysis of China's Foreign Relations (1949-2009). Beijing: Social Sciences Academic Press, 2009. 